\title{
The Role of Accruals and Cash Flows in Forecasting GDP Growth
}

\begin{abstract}
This study examines the informativeness of accruals and cash flows for growth in nominal Gross Domestic Product (GDP). Prior literature documents that aggregate accounting earnings growth is a significant leading indicator of future GDP growth. I further examine the role of aggregate cash flows and accruals in forecasting GDP growth, as well as the relation between aggregate accounting earnings growth and contemporaneous GDP growth. The findings suggest that decomposition of aggregate accounting earnings growth improves the predictive ability of future GDP growth for the longer forecast horizons. Although aggregate cash flows growth and aggregate accruals growth are significant indicators of future GDP growth, professional macro forecasters do not incorporate their predictive content into their GDP growth forecasts. In addition, the predictive content of aggregate accruals and cash flows growth persist over longer horizons than that of contemporaneous GDP growth. The findings suggest that aggregate accruals and cash flows growth contains useful information that is not captured by contemporaneous GDP growth.
\end{abstract}

Keywords: Accounting earnings, Accruals, Cash flows, Corporate profits, Gross Domestic Product (GDP). 


\section{Introduction}

This study examines the informativeness of accruals and cash flows for growth in Gross Domestic Product (GDP), in order to shed light on the role of accounting information in forecasting GDP growth. The link between the key summary statistics of economic activity and the key summary statistics of firms is relatively unexplored.

GDP is the most important variable in analyses of economic growth (e.g., Henderson et al., 2012). It is used by the White House and Congress to prepare the U.S. Federal Budget, by the Federal Reserve to formulate monetary policy, by Wall Street as an indicator of economic activity, and by the business community as a key factor for production, investment, and employment decisions.

One of the traditional ways to measure GDP is the income approach, which sums corporate profits, employee compensation, and taxes on production and imports. The U.S. Bureau of Economic Analysis (BEA) uses the income approach to measure GDP and measures corporate profits based on the annual tabulation of corporate income tax returns by the Internal Revenue Service (IRS). Konchitchki and Patatoukas (2014) propose an alternative way to measure corporate profits. They suggest using aggregate accounting earnings data, prepared according to Generally Accepted Accounting Principles (GAAP). Konchitchki and Patatoukas (2014) also argue that since prior literature finds that accounting earnings predict future cash flows better than current cash flows do (e.g., Dechow et al., 1998), accounting earnings probably predict future taxable income, which is cash-based, better than current taxable income does. Although accounting earnings data do not include private corporations' earnings and do not align with taxable income criteria, they can be a good proxy for corporate profits.

Prior literature (Konchitchki and Patatoukas, 2014; Nallareddy and Ogneva, 2017) documents that aggregate accounting earnings growth is a significant leading indicator of 
future GDP growth, and professional macro forecasters do not incorporate the predictive content of aggregate accounting earnings growth into their GDP growth estimates.

This study examines the informativeness of accruals and cash flows for growth in nominal GDP. I further examine the role of aggregate cash flows and accruals in forecasting GDP growth, as well as the relation between aggregate accounting earnings growth and contemporaneous GDP growth.

The motivation for this study is based on the following reasoning. First, cash component of earnings is more persistent than the accrual component. Previous studies examine the differential information content of the cash flow and accrual components of earnings (e.g., Graham et al., 1962; Bernstein, 1993). While both components contribute to current earnings, current earnings performance is less likely to persist if it is attributable primarily to the accrual component of earnings as opposed to the cash flow component (e.g., Sloan, 1996).

Second, there is no consensus in prior literature about which measure is superior in predicting future cash flows. The findings on the relative predictive abilities of earnings and cash flows are mixed. Several studies document that earnings are better than current cash flows in predicting future cash flows (e.g., Dechow et al., 1998; Kim and Kross, 2005; Nam et al., 2012), while others document that cash flows are better (e.g., Subramanyam and Venkatachalam, 2007; Chen et al., 2017). In addition, Nallareddy, Sethuraman, and Venkatachalam (2018) find that the ability of earnings to predict future cash flows is increasing over the period 1989-2015, and that this trend is attributable to the increasing predictive ability of cash flows rather than accruals. They suggest that the reason for the prior mixed findings is mainly measurement errors induced by the balance sheet method of estimating cash flows.

My research design follows that of prior literature (Konchitchki and Patatoukas, 2014; Nallareddy and Ogneva, 2017) and carefully aligns accounting earnings reports of individual firms with the release of the BEA's GDP report schedule. I create an index of aggregate 
accounting earnings, cash flows, and accruals growth, based only on real-time quarterly reports. I measure aggregate earnings, cash flows, and accruals growth, using a broad sample of quarterly reports over the period Q1:1988-Q4:2017.

The findings suggest that decomposition of aggregate accounting earnings growth to cash flow component and accrual component improves the predictive ability of future GDP growth for the longer forecast horizons. Across forecast horizons from one to four quarters ahead, the adjusted R-squared of the model based on decomposition is greater than the adjusted R-squared of the model based on aggregation. Although, aggregate cash flows growth and aggregate accruals growth are significant indicators of future GDP growth, professional macro forecasters do not incorporate their predictive content into their GDP growth forecasts.

Also, consistent with the findings of prior literature (Konchitchki and Patatoukas, 2014; Nallareddy and Ogneva, 2017), the results suggest that (i) aggregate accounting earnings growth is a significant leading indicator of future GDP growth, (ii) the predictive content of aggregate accounting earnings growth for future GDP growth is economically important and incremental to contemporaneous GDP growth, and (iii) professional macro forecasters do not incorporate the predictive content of aggregate accounting earnings growth into their GDP growth forecasts. Furthermore, real-time aggregate accounting earnings growth can predict forecasts errors in future GDP growth.

Finally, the findings suggest that the predictive content of aggregate accounting earnings growth persists over longer horizons than that of contemporaneous GDP growth. Aggregate accounting earnings growth contributes to forecast GDP growth up to four quarters ahead, while contemporaneous GDP growth contributes to forecast GDP growth only up to two quarters ahead. The evidence suggests that aggregate accounting earnings growth contains useful information that is not captured by contemporaneous GDP growth. 
This study contributes to the accounting and economics literature by shedding light on the informativeness of real-time, publicly available accounting data for GDP growth. This study also contributes to macroeconomics research by documenting that aggregate accounting earnings growth contains useful information that is not captured by contemporaneous GDP growth. Further, this study contributes to the U.S. economy and the business community by improving future GDP growth forecasts.

The rest of the paper is organized as follows. Section 2 reviews the related literature and presents the main empirical predictions. Section 3 describes the empirical research design. Section 4 outlines the data, timeline, and descriptive statistics. Section 5 presents the empirical results and Section 6 concludes.

\section{Literature review and hypotheses development}

\subsection{Literature review}

One of the traditional ways to measure GDP is the income approach, which sums corporate profits, employee compensation, and taxes on production and imports. The U.S. Bureau of Economic Analysis (BEA) uses the income approach to measure GDP and measures corporate profits based on the annual tabulation of corporate income tax returns by the Internal Revenue Service (IRS). Konchitchki and Patatoukas (2014) propose an alternative way to measure corporate profits. They suggest using aggregate accounting earnings data, prepared according to Generally Accepted Accounting Principles (GAAP). Konchitchki and Patatoukas (2014) also argue that since prior literature finds that accounting earnings predict future cash flows better than current cash flows do (e.g., Dechow et al., 1998), accounting earnings probably predict future taxable income, which is cash-based, better than current taxable income does. Although accounting earnings data do not include private corporations' earnings and do not align with taxable income criteria, they can be a good proxy for corporate profits. 
Konchitchki and Patatoukas (2014) document that aggregate accounting earnings growth is a significant leading indicator of future GDP growth, and professional macro forecasters do not incorporate the predictive content of aggregate accounting earnings growth into their GDP growth estimates.

\subsection{Hypotheses development}

First, the importance of analyzing the accrual and cash components of current earnings in the assessment of future earnings is emphasized in prior literature (e.g., Graham et al., 1962; Bernstein, 1993). The common idea underlying this reasoning is that the accrual and cash flow components of current earnings have different implications for the assessment of future earnings. The findings show that the cash component of earnings is more persistent than the accrual component of earnings. The persistence of earnings performance is shown to depend on the relative magnitudes of the cash and accrual components of earnings (e.g., Sloan, 1996).

Building on previous findings which suggest that the cash component of earnings is more persistent than the accrual component (e.g., Sloan, 1996), and Konchitchki and Patatoukas (2014) findings that aggregate accounting earnings growth is a significant leading indicator of future GDP growth, I predict that decomposition of aggregate accounting earnings growth to cash flows component and accrual component improves the predictability of future GDP growth. This forms the basis for the first testable hypothesis:

H1: The predictive ability of decomposition of aggregate accounting earnings growth is greater than the predictive ability of aggregate accounting earnings growth.

Second, there is a long line of research that examines the relative ability of earnings and cash flows to predict future cash flows. The findings on the relative predictive ability of earnings and cash flows are mixed, and there is no consensus about which measure is superior. Several studies document that earnings are better than current cash flows in predicting future cash flows (e.g., Brooks, 1982; Greenberg et al., 1986; Lorek and Willinger, 1996; Dechow et 
al., 1998; Kim and Kross, 2005; Nam et al., 2012), while other studies document that cash flows are better (e.g., Bowen et al., 1986; Finger, 1994; Burgstahler et al.,1998; Subramanyam and Venkatachalam, 2007; Lorek and Willinger, 2009; Chen et al., 2017; Nallareddy, Sethuraman, and Venkatachalam, 2018). In addition, Nallareddy, Sethuraman, and Venkatachalam (2018) find that the ability of earnings to predict future cash flows is increasing over the period 1989-2015. However, this trend is attributable to the increasing predictive ability of cash flows rather than accruals. They suggest that the reason for the previous mixed results is mainly measurement errors induced by the balance sheet method of estimating cash flows.

Building on previous findings which suggest that cash flows are better than earnings in predicting future cash flows, and Nallareddy, Sethuraman, and Venkatachalam (2018) findings that the ability of earnings to predict future cash flows is increasing due to the increasing predictive ability of cash flows rather than accruals, I predict that the cash flows component predicts future GDP growth more accurately than the accrual component. This forms the basis for the second testable hypothesis:

H2: The predictive ability of aggregate cash flows growth is greater than the predictive ability of aggregate accruals growth.

Third, it is ex ante unclear whether aggregate accounting earnings growth supplements or substitutes for contemporaneous GDP growth in predicting future GDP growth. In order to explore the relation between aggregate accounting earnings growth and contemporaneous GDP growth, I examine the predictive ability of contemporaneous GDP growth relative to the predictive ability of aggregate accounting earnings growth and the decomposition of earnings. This empirical question, without an ex ante prediction, forms the basis for the third testable hypothesis: 
H3: The predictive ability of aggregate accounting earnings growth is unrelated to the predictive ability of contemporaneous GDP growth in predicting future GDP growth.

Finally, Konchitchki and Patatoukas (2014) document that professional macro forecasters do not incorporate the predictive content of aggregate accounting earnings growth into their GDP growth forecasts. Since professional macro forecasters do not incorporate earnings, which is the key summary statistic of firms, I predict that professional macro forecasters do not fully incorporate the cash flows and accrual components of earnings. This forms the basis for the fourth testable hypothesis:

H4: Aggregate cash flows growth and aggregate accruals growth predict GDP growth forecast errors.

\section{Research Design}

\subsection{Accounting data and future GDP growth}

\subsubsection{Earnings and future GDP growth}

To examine the informativeness of accounting earnings data for future GDP growth, I use two different models to test whether aggregate accounting earnings growth is associated with future GDP growth for horizons ranging from one to four quarters ahead. Model A tests whether aggregate accounting earnings growth contributes to forecast GDP growth up to four quarters ahead. Model B tests whether aggregate accounting earnings contributes incremental information about future GDP growth, after controlling for contemporaneous GDP growth.

Model A: $g_{q+k}=\alpha_{k}+\beta_{k} \Delta X_{q}+\varepsilon_{q+k}$

Model B: $g_{q+k}=\alpha_{k}+\beta_{k} \Delta X_{q}+\gamma_{k} g_{q}+\varepsilon_{q+k}$,

where $g_{q}$ is GDP growth for quarter $q, g_{q+k}$ is GDP growth for quarter $q+k, k=\{1,2,3,4\}$, and $\Delta X_{q}$ is aggregate accounting earnings growth for quarter $q$. 
The slope coefficients $\beta_{k}$ on $\Delta X_{q}$ are the coefficients of interest. An estimate of $\beta_{k}$ that is statistically significant for any of the horizons considered suggests that aggregate accounting earnings growth is informative about GDP growth for that horizon.

\subsubsection{Decomposition of earnings and future GDP growth}

To examine the informativeness of aggregate cash flows and accruals growth for future GDP growth, I test whether aggregate accounting cash flows (accruals) growth is associated with future GDP growth for horizons ranging from one to four quarters ahead using two different models (H1). Further, I test whether there is a difference between the informativeness of the cash flow component and the accrual component $(\mathrm{H} 2)$.

Model $\mathrm{C}$ tests whether decomposition of aggregate accounting earnings growth contributes to forecast GDP growth up to four quarters ahead. Model D tests whether decomposition of aggregate accounting earnings contributes incremental information about future GDP growth after controlling for contemporaneous GDP growth.

Model C: $g_{q+k}=\alpha_{k}+\beta_{k} \Delta C F_{q}+\delta_{k} \Delta A C C_{q}+\varepsilon_{q+k}$

Model D: $g_{q+k}=\alpha_{k}+\beta_{k} \Delta C F_{q}+\delta_{k} \Delta A C C_{q}+\gamma_{k} g_{q}+\varepsilon_{q+k}$,

where $g_{q}$ is GDP growth for quarter $q, g_{q+k}$ is GDP growth for quarter $q+k, k=\{1,2,3,4\}, \Delta C F_{q}$ is aggregate cash flows growth for quarter $q$, and $\triangle A C C_{q}$ is aggregate accruals growth for quarter $q$.

The slope coefficients $\beta_{k}\left(\delta_{k}\right)$ on $C F_{q}\left(A C C_{q}\right)$ are the coefficients of interest. An estimate of $\beta_{k}\left(\delta_{k}\right)$ that is statistically significant for any of the horizons considered suggests that aggregate cash flows (accruals) growth is informative about GDP growth for that horizon. Statistically different coefficients for the cash flow and accrual components suggest that their 
predictive ability is different. In order to examine the difference between the coefficients of interest, I use the F-test method.

In addition, I compare the adjusted R-squared of model C (D) to model A (B). The higher adjusted R-squared for model C (D) suggests that decomposition of earnings improves the predictive ability of future GDP growth. Since the comparison of adjusted R-squared of non-nested models is associated with several econometric problems (e. g. Greene, 2003, Kennedy, 2008), I perform the Vuong (1989) test, to investigate whether the difference in adjusted R-squared is significant at conventional levels.

\subsection{Comparing earnings and contemporaneous GDP growth}

To examine the informativeness of accounting earnings data for future GDP growth relative to contemporaneous GDP growth, I test whether the predictive ability of aggregate accounting earnings growth is different than the predictive ability of contemporaneous GDP growth for horizons ranging from one to four quarters ahead (H3). I use Models A, B, C, and D from the previous sections, and add Model E, which tests whether contemporaneous GDP growth contributes to forecast GDP growth up to four quarters ahead.

Model E: $g_{q+k}=\alpha_{k}+\gamma_{k} g_{q}+\varepsilon_{q+k}$

The slope coefficients $\gamma_{k}$ on $g_{q}$ are the coefficients of interest. An estimate of $\gamma_{k}$ that is statistically significant for any of the horizons considered suggests that contemporaneous GDP growth is informative about GDP growth for that horizon. In addition, the model with the highest adjusted R-squared is the best model for predicting future GDP growth.

\subsection{Accounting data and future GDP growth forecast errors}

\subsubsection{Earnings and future GDP growth forecast errors}


To examine whether professional macro forecasters incorporate accounting earnings into their projections of future GDP growth, I first measure GDP growth forecast errors as the difference between realized GDP growth and the SPF consensus forecast of GDP growth. Again, using two different models, I test whether aggregate accounting earnings growth predicts future GDP growth forecast errors, for horizons ranging from one to four quarters ahead. Model A tests whether aggregate accounting earnings growth predicts future GDP growth forecast errors up to four quarters ahead, and Model B includes GDP growth for quarter $q$ as a control variable.

GDP Growth Forecast Error $_{q+k}=g_{q+k}-E_{q}^{S P F}\left(g_{q+k}\right)$

Model A: $\left[g_{q+k}-E_{q}^{S P F}\left(g_{q+k}\right)\right]=\alpha_{k}+\beta_{k} \Delta X_{q}+\varepsilon_{q+k}$

Model B: $\left[g_{q+k}-E_{q}^{S P F}\left(g_{q+k}\right)\right]=\alpha_{k}+\beta_{k} \Delta X_{q}+\gamma_{k} g_{q}+\varepsilon_{q+k}$,

where $g_{q+k}$ is GDP growth for quarter $q+k$, and $E_{q}^{S P F}\left(g_{q+k}\right)$ is the mean SPF consensus forecast of GDP growth for quarter $q+k$ at quarter $q$.

The slope coefficients $\beta_{k}$ on $\Delta X_{q}$ are the coefficients of interest. An estimate of $\beta_{k}$ that is statistically significant for any of the horizons considered suggests that aggregate accounting earnings growth is informative about GDP growth for that horizon, and that professional macro forecasters do not fully incorporate this information into their predictions of future GDP growth. A positive (negative) estimate of $\beta_{k}$ indicates that professional macro forecasters underreact (overreact) to the predictive content of aggregate accounting earnings growth for future GDP growth. In contrast, because professional macro forecasters fully impound the accounting earnings information into their predictions of future GDP, an estimate of $\beta_{k}$ that is statistically insignificant suggests that GDP growth for forecast errors for quarter $q+k$ are not related to aggregate accounting earnings growth in quarter $q$. 


\subsubsection{Decomposition of earnings and future GDP growth forecast errors}

To examine whether professional macro forecasters incorporate accounting earnings decomposition into their projections of future GDP growth (H4), I first measure GDP growth forecast errors. I then test, using two different models, whether aggregate cash flows (accruals) growth predicts future GDP growth forecast errors, for horizons ranging from one to four quarters ahead.

Model $\mathrm{F}$ tests whether aggregate cash flows (accruals) growth predicts future GDP growth forecast errors up to four quarters ahead, and Model G includes GDP growth for quarter $q$ as a control variable.

Model F: $\left[g_{q+k}-E_{q}^{S P F}\left(g_{q+k}\right)\right]=\alpha_{k}+\beta_{k} \Delta C F_{q}+\delta_{k} \Delta A C C_{q}+\varepsilon_{q+k}$

Model G: $\left[g_{q+k}-E_{q}^{S P F}\left(g_{q+k}\right)\right]=\alpha_{k}+\beta_{k} \Delta C F_{q}+\delta_{k} \Delta A C C_{q}+\gamma_{k} g_{q}+\varepsilon_{q+k},(6)$

where $g_{q+k}$ is GDP growth for quarter $q+k$, and $E_{q}^{S P F}\left(g_{q+k}\right)$ is the mean SPF consensus forecast of GDP growth for quarter $q+k$ at quarter $q$.

The slope coefficients $\beta_{k}\left(\delta_{k}\right)$ on $C F_{q}\left(A C C_{q}\right)$ are the coefficients of interest. An estimate of $\beta_{k}\left(\delta_{k}\right)$ that is statistically significant for any of the horizons considered suggests that aggregate cash flows (accruals) growth is informative about GDP growth for that horizon, and that professional macro forecasters do not fully impound this information into their predictions of future GDP growth. A positive estimate of $\beta_{k}\left(\delta_{k}\right)$ indicates an underreaction, while a negative estimate indicates an overreaction of professional macro forecasters to the predictive content of aggregate cash flows (accruals) growth for future GDP growth. In contrast, an insignificant estimate suggests that professional macro forecasters fully impound the cash flows (accruals) information into their predictions of future GDP. 
I estimate all the models using ordinary least squares regressions, and I base my inferences on Newey and West (1987) heteroscedasticity and auto consistent standard error. The Newey and West (1987) procedure accounts for heteroscedasticity and serial correlation of unknown form in the residuals. I set the lag length equal to the integer part of $T^{0.25}$, where $T$ is the number of observations, following Greene (2011, p.920). The number of observations is 119 , therefore the lag length is equal to three. All my inferences are not sensitive to using White's (1980) heteroscedasticity consistent standard errors.

\section{Sample, timeline, and descriptive statistics}

\subsection{Sample}

I obtain all real-time accounting data from the Compustat Quarterly Preliminary History dataset. The sample starts in Q1:1988, the first quarter for which real-time accounting data exists. The sample covers the period from Q1:1988 to Q4:2017, excluding Q4:1995. Due to a government shutdown, the relevant data for Q4:1995 is unavailable and not included

The sample includes only firm-quarter observations with non-missing data for market value of equity, earnings, earnings growth, and the quarterly earnings announcement date.

Following prior literature (Konchitchki and Patatoukas, 2014; Nallareddy and Ogneva, 2017), for firm $i$ in quarter $q$, I measure earnings $\left(X_{i, q}\right)$ as quarterly net income scaled by sales, and earnings growth $\left(\Delta X_{i, q}\right)$ as the year-over-year change in scaled quarterly net income. Cash flows $(C F)$ are measured as quarterly cash flows from operations adjusted for extraordinary items and discontinued operations, as derived from cash flow statements, scaled by sales. Accruals $(A C C)$ are measured as the difference between earnings $\left(X_{i, q}\right)$ and cash flows $(C F)$. I scale the key variables by sales to be consistent with Konchitchki and Patatoukas (2014), but my inferences are not sensitive to scaling by either lagged total assets or lagged book value of equity. 
I construct aggregate quarterly time series of earnings growth, cash flows growth and accruals growth, using value-weighted cross-sectional averages with weights based on lagged market capitalization. Value-weighted cross-sectional averages take into account the relative economic importance of each firm (e.g., Gondes, 1973). My inferences are not sensitive to using the equally-weighted averages or using net income the year-over-year change in net income scaled by sales.

I obtain the BEA "advance" and "final" estimates of realized GDP growth in nominal terms from the Real-Time Data Set for Macroeconomists of the Federal Reserve Bank of Philadelphia in its National Income and Product Accounts (NIPA). I focus on nominal GDP growth, because accounting earnings are not adjusted for inflation. The BEA reports the advance estimate of GDP growth at the end of the first month after the quarter ends and is based on incomplete data. The BEA reports the final estimate of GDP growth at the end of the third month after the quarter ends. The final estimate is actually the second revision of the advance estimate and is based on more accurate source data (e.g., Romer and Romer, 2000; Faust and Wrights, 2007; Landfeld et al., 2008).

I obtain the mean consensus Survey of Professional Forecasters (SPF) forecasts of GDP growth from the Federal Reserve Bank of Philadelphia. The SPF is the best and longest publicly available survey of quarterly macroeconomic forecasts and has been used in prior research (e.g., Sims, 2002; Ang et al., 2007). Prior studies find that professional macro forecasters outperform time-series models (e.g., Zarnowitz and Braun, 1993; Stark, 2010). In addition, the consensus SPF forecasts consistently outperform the forecasts of individual and therefore are the most appropriate measure for this analysis (e.g., Zarnowitz and Brown, 1993; Croushore, 2011). My inferences are not sensitive to using the median consensus SPF forecasts of GDP growth, because the distribution of the individual panelists is fairly symmetric around the mean. 
Following Konchitchki and Patatoukas (2014), I measure GDP forecasts errors across forecast horizons from one to four quarters ahead, using the BEA's final estimate of GDP growth. The final estimate for GDP growth is better than the advance estimate for measuring GDP growth forecasts errors, because it is based on more complete data. In addition, it is the preferred estimate of the Federal Reserve Bank of Philadelphia for evaluating the forecasts accuracy of SPF panelists.

The SPF panelists' incentives align with the strongest incentives to produce accurate forecasts. Their forecasts are indistinguishable from the forecasts of the Research Staff of the Federal Reserve Board of Governors. Because its forecasts are used for monetary policy, the Research Staff of the Federal Reserve Board of Governors is incentivized to provide accurate forecasts of the U.S. economy. The SPF panelists are further incentivized to produce accurate forecasts, because they likely face reputational costs if they fail to do so.

\subsection{Timeline}

This study evaluates whether accounting data can help macro forecasters predict GDP growth based on real-time, publicly available accounting earnings data. Therefore, the sample includes only firm-quarter observations with accounting earnings releases that were available to SPF panelists in real time, at the time of forecasting future GDP growth.

The timeline of the research design perfectly matches the timeline of the SPF in Fig.1 of Konchitchki and Patatoukas (2014). The timing of the SPF closely follows the release of the BEA's advance estimate of GDP growth. By the end of the first month after the quarter ends, the survey questionnaires are sent to macro forecasters. The deadline for responses is in the middle of the second month after the quarter ends. Although the feasible information set of the SPF panelists includes all earnings announcements published by the middle of the second month after the quarter ends, I retain accounting earnings data only for firms with quarterly 
earnings announcements released by the first month after the quarter ends. I follow the conservative approach of Konchitchki and Patatoukas (2014), to assure macro forecasters have time to process publicly available accounting data. Because they are not available to SPF panelists in real time, I do not use the BEA's estimates of corporate profit growth.

As an example, consider the timing of the first quarter SPF for 2010 in Fig.2 of Konchitchki and Patatoukas (2014). The advance estimate of GDP growth for Q4:2009 was released by the BEA on January 29, 2010. By January 31, 2010, the Federal Reserve Bank of Philadelphia sent the survey questionnaires to the SPF panelists. The forecasters were asked to fill out the survey questionnaires by the middle of February, i.e., before the first and second revisions of the advance estimate of GDP growth for Q4:2009 were released by the BEA on February 26, 2010 and March 26, 2010, respectively. Corporate profits for Q4:2009 were initially announced with a three-month lag on March 26, 2010. Clearly, the feasible information set available to SPF panelists by the time they filled out and submitted the survey questionnaires does not include corporate profits. Thus, the feasible information set available to SPF panelists by the time they received the survey questionnaires included the advance estimate of GDP growth for Q4:2009 and accounting earnings data for Q4:2009 that were announced by the middle of February, 2010.

\subsection{Descriptive statistics}

Table 1 presents the descriptive statistics for the key variables. Mean aggregate accounting earnings growth is 0.03 percent with a standard deviation of 2.08 percent. Mean aggregate cash flows growth is 2.86 percent with a standard deviation of 24.38 percent. Mean aggregate accruals growth is -2.68 percent with a standard deviation of 24.45 percent. Mean realized GDP growth is 4.45 percent with a standard deviation of 2.19 percent. For the one 
quarter ahead forecast horizon, the average GDP growth forecast error is 0.12 percent with a standard deviation of 2.53 percent.

Table 2 presents the correlation coefficients of the key variables. Aggregate accounting earnings is positively related to contemporaneous GDP growth. The Pearson (Spearman) correlation between aggregate accounting earnings growth and contemporaneous GDP growth is 43.49 (27.17) percent. As expected, cash flows growth and accruals growth are negatively correlated. Specifically, the Pearson (Spearman) correlation between accruals growth and cash flows growth is $-92.03(-88.69)$ percent and is statistically significant. Overall, correlations among variables in my sample are as expected and in line with prior research.

\section{Empirical results}

\subsection{Accounting data and future GDP growth}

\subsubsection{Earnings and future GDP growth}

Table 3 reports results from the regression models of future GDP growth as described in equation (1). Based on Model A, the results show that the estimated slope coefficients $\beta_{k}$ are significantly positive and equal to $0.462,0.450,0.395$, and 0.263 , for forecasts horizons from one to four quarters ahead, respectively.

Based on Model B, the results show that the predictive content of aggregate accounting earnings growth for future GDP growth is incremental to that of contemporaneous GDP growth. After controlling for GDP growth in quarter $q$, the estimated slope coefficients $\beta_{k}$ remain significantly positive and equal to $0.277,0.363$, and 0.350 , for forecasts horizons from one to three quarters ahead, respectively.

In addition, for the one quarter ahead forecast horizon the adjusted R-squared for Model A is 11.94 percent, while the adjusted R-squared for Model B is 19.93 percent. 
These findings are consistent with previous findings (e.g., Konchitchki and Patatoukas, 2014) and suggest that aggregate accounting earnings growth is a significant leading indicator of future GDP growth. The link between aggregate accounting earnings growth and future GDP growth is both statistically significant and economically important.

\subsubsection{Decomposition of earnings and future GDP growth}

Table 4 reports results from the regression models of future GDP growth as described in equation (4). Based on Model C, the results from regressions of GDP growth in quarter $q+k$ on aggregate cash flows (accruals) growth in quarter $q$ show that the estimated slope coefficients are significantly positive and equal to $0.608(0.522), 0.797(0.592), 0.667(0.507)$, and (0.364), for forecasts horizons from one to four quarters ahead, respectively. Based on the F-test results, the difference between the coefficients is statistically significant at conventional levels only for forecasts horizons from two to three quarters ahead.

Based on Model D, the results show that the predictive content of aggregate cash flows growth and aggregate accruals growth for future GDP growth is incremental to that of contemporaneous GDP growth. After controlling for GDP growth in quarter $q$, the estimated slope coefficients of the cash flows (accruals) component remain significantly positive and equal to $0.408(0.332), 0.706(0.505)$, and $0.62(0.463)$, for forecasts horizons from one to three quarters ahead, respectively.

In addition, comparison of the results of Table 3 and Table 4 suggests that there is an increase in adjusted R-squared, as a result of the decomposition of earnings to cash flows and accruals, for forecasts horizons from two to four quarters ahead. The adjusted R-squared for Model A (C) is 11.94 (11.75), 11.86 (14.46), 8.75 (9.97), and 3.46 (4.2) percent, while the adjusted R-squared for Model B (D) is 19.93 (19.68), 13.06 (15.59), 8.45 (9.61), and 3.5 (4.14) percent, for forecasts horizons from one to four quarters ahead, respectively. The negative 
difference between the adjusted R-squared of model A (B) and model C (D), suggests that model B (D) is better than model C (D) in predicting future GDP growth. Adjusted R-squared are compared, using the likelihood ratio test described in Vuong (1989). The test returns the value of Vuong's diagnostic statistic, comparing the residual component of Model A (B) to the residual component of Model C (D), respectively. P-value indicates the two-tailed significance level for the difference in the explanatory power of the models. The Vuong test indicates that the difference in adjusted R-squared is significant at conventional levels only for forecasts horizons from two to three quarters ahead.

These findings suggest that both aggregate cash flows growth and aggregate accruals growth are significant leading indicators of future GDP growth. The link between aggregate accounting cash flows (accruals) growth and future GDP growth is both statistically significant and economically important. Furthermore, the decomposition of earnings to cash flows and accruals improves the ability of earnings to predict longer horizons of GDP growth.

Overall, there is evidence for a difference in the predictive ability of cash flows and accruals, but I cannot conclude that the cash flows predictive ability is higher than the accruals predictive ability. It is probably because this small sample size lacks statistical power. Unfortunately, I cannot increase the sample size, because it is already using the maximum available data.

\subsection{Comparing earnings and contemporaneous GDP growth}

Table 5 reports results from the regression models of future GDP growth as described in Model E. Recall that Models A and C include only accounting information, while Models B and D include both accounting and contemporaneous GDP growth information.

Based on Model E, the results from regressions of GDP growth in quarter $q+k$ on contemporaneous GDP growth in quarter $q$ show that the estimated slope coefficients are 
significantly positive and equal to $0.515,0.341,0.242$, and 0.213 for forecasts horizons from one to four quarters ahead, respectively. Based on the results in Tables 3 and 5, the estimated slope coefficients on contemporaneous GDP growth are statistically significant for forecasts horizons from one to two only. It seems that for longer forecasts horizons, the predictive ability of aggregate accounting earnings growth subsumes the predictive ability of contemporaneous GDP growth.

In addition, the adjusted R-squared for Model A (C) is 11.94 (11.75), 11.86 (14.46), 8.75 (9.97), and 3.46 (4.2) percent, while the adjusted R-squared for Model E is 16.9, 7.19, 3.18, and 2.31 percent, for forecasts horizons from one to four quarters ahead, respectively. It seems that aggregate accounting earnings growth can predict better than contemporaneous GDP growth, for forecasts horizons from two to four quarters ahead.

\subsection{Accounting data and future GDP growth forecast errors}

\subsubsection{Earnings and future GDP growth forecast errors}

Table 6 reports results from the regression models of future GDP growth forecast errors as described in equation (3). The results from regressions of GDP growth forecast errors in quarter $q+k$ on aggregate accounting earnings growth in quarter $q$ based on Model A show that the estimated slope coefficients $\beta_{k}$ are significantly positive and equal to 0.235 , and 0.260 , for forecasts horizons from two to three quarters ahead, respectively.

Based on Model B, the results show that the predictive content of aggregate accounting earnings growth for future GDP growth forecast errors continues to hold. After controlling for GDP growth in quarter $q$, the estimated slope coefficients $\beta_{k}$ remain significantly positive and equal to 0.290 , and 0.304 , for forecasts horizons from two to three quarters ahead, respectively

The findings suggest that professional macro forecasters underreact to the predictive content of aggregate accounting earnings growth for future GDP growth forecast errors. In 
addition, the results show that GDP growth in quarter $q$ is unrelated to future GDP growth forecast errors. These results are trivial, because it is clear that professional macro forecasters fully impound the information of contemporaneous GDP growth.

\subsubsection{Decomposition of earnings and future GDP growth forecast errors}

Table 7 reports results from the regression models of future GDP growth forecast errors as described in equation (6). Based on Model A, the results from regressions of GDP growth forecast errors in quarter $q+k$ on aggregate cash flows (accruals) growth in quarter $q$ show that the estimated slope coefficients are significantly positive and equal to $0.521(0.352)$, and 0.45 (0.338), respectively, for forecasts horizons from two to three quarters ahead.

Based on Model B, the results show that the predictive content of aggregate accounting earnings growth for future GDP growth forecast errors continues to hold. After controlling for GDP growth in quarter $q$, the estimated slope coefficients remain significantly positive and equal to $0.582(0.411)$, and $0.5(0.386)$, for forecasts horizons from two to three quarters ahead, respectively. Based on the F-test results, the difference between the coefficients is statistically significant at conventional levels only for forecasts horizons of two quarters ahead.

In addition, comparison of the results of Table 6 and Table 7 suggests that there is a slight increase in adjusted R-squared, as a result of the decomposition of earnings to cash flows and accruals for forecasts horizons from two to three quarters ahead. The adjusted R-squared for Model A (F) is $0.32(-0.22), 3.07$ (4.81), 3.46 (3.66), and 1.27 (1.2) percent, while the adjusted R-squared for Model B (G) is $0.06(-0.47), 3.13$ (4.96), 3.14 (3.38), and 0.39 (0.32) percent, for forecasts horizons from one to four quarters ahead, respectively. The negative difference between the adjusted R-squared of model A (B) and model F (G), suggests that model B (D) is better than model C (D) in predicting future GDP growth, for forecasts horizons from two to three quarters ahead. However, the Vuong (1989) test indicates that the difference 
in adjusted R-squared is not significant at conventional levels. It is probably because this small sample size lacks statistical power.

The findings suggest that professional macro forecasters underreact to the predictive content of aggregate cash flows growth and aggregate accruals growth for future GDP growth forecast errors. In addition, the results show that GDP growth in quarter $q$ is unrelated to future GDP growth forecast errors. These results are not surprising because it is clear that professional macro forecasters fully impound the information of contemporaneous GDP growth.

\section{Conclusion}

This study contributes to the accounting and economics literature by shedding light on the informativeness of accounting information for GDP growth. The findings suggest that aggregate accruals and cash flows growth are significant leading indicators of future GDP growth, and professional macro forecasters do not incorporate the predictive content of aggregate accruals and cash flows growth into their GDP growth forecasts. Further, real-time aggregate accruals and cash flows growth can predict future GDP growth forecasts errors.

In addition, decomposition of aggregate accounting earnings growth to cash flows component and accrual component improves the predictive ability of future GDP growth for the longer forecast horizons, relative to aggregate accounting earnings growth.

Interestingly, in predicting future GDP growth, aggregate accounting data is more persistent than contemporaneous GDP growth. For longer forecasts horizons, the predictive ability of aggregate accounting earnings growth subsumes the predictive ability of contemporaneous GDP growth. A related direction for additional research is to further examine these findings, in order to shed light on the uniqueness of earnings in predicting longer forecasts horizons. 


\section{References}

Abarbanell, J., 1991. Do analysts' earnings forecasts incorporate information in prior stock price changes? Journal of Accounting and Economics14 (2), 147-165.

Ang, A., Bekaert, G.,Wei, M.,2007.Do macro variables, asset markets, or surveys forecast inflation better? Journal of Monetary Economics 54 (4), 1163-1212.

Ang, A., Piazzesi, M., Wei, M., 2005. What does the yield curve tell us about GDP growth? Journal of Econometrics 131(1-2), 359-403.

Baghestani, H., Kianian, A. M., 1993. On the rationality of U.S. macroeconomic forecasts: evidence from a panel of professional forecasters. Applied Economics 25(7), 869-878.

Ball, R., Sadka, G., Sadka, R., 2009. Aggregate earnings and asset prices. Journal of Accounting Research 47 (5), 1097-1133.

Barth, M.E., Cram, D.P., Nelson, K.K., 2001. Accruals and the Prediction of Future Cash Flows. The Accounting Review 76 (1), 27-58.

Beaver, W.H., 1998. Financial reporting: an accounting revolution, Third Edition. New Jersey: Prentice-Hall.

Bradshaw, M.T., 2011. Analysts' forecasts: what do we know after decades of work? Working paper.

Bradshaw, M.T., Drake, M.S., Myers, J.N., Myers, L.A., 2012. A re-examination of analysts' superiority over time-series forecasts of annual earnings. Review of Accounting Studies 17(4), $1-25$.

Bureau of Economic Analysis, 2002. Corporate Profits: Methodology Paper. United States Department of Commerce, Economics and Statistics Administration, Bureau of Economic Analysis.

Bureau of Economic Analysis, 2004. Corporate profits in the GDP accounts. BEA paper series, No.0040. United States Department of Commerce, Economics and Statistics Administration, Bureau of Economic Analysis.

Bureau of Economic Analysis, 2007. Measuring the Economy: A Primer of GDP and the National Income and Product Accounts. United States Department of Commerce, Economics and Statistics Administration, Bureau of Economic Analysis.

Chen, C. W., Melessa, S., Mergenthaler, R., 2017. Revisiting Measurement Error in Surrogate Measures of Operating Cash Flows: Have We Solved the Problem? Working Paper.

Chung, R., Kryzanowski, L., 1999. Accuracy of consensus expectations for top-down earnings per share forecasts for two S\&P indexes. Applied Financial Economics 9(3), 233-238.

Clarida, R., Gali, J., Gertler, M., 2000. Monetary policy rules and macroeconomic stability: evidence and some theory. Quarterly Journal of Economics 115(1), 147-180.

Croushore, D.D., 2011. Real time forecasting. In: Higgins, Matthew L.(Ed.), Advances in Economic Forecasting, W.E. Upjohn Institute for Employment Research, Kalamazoo, MI, pp.7-24.

Darrough, M.N., Russell, T., 2002. A positive model of earnings forecasts: top down versus bottom up. Journal of Business 75(1), 127-152. 
Dechow, P.M., Kothari, S.P., Watts, R.L., 1998. The relation between earnings and cash flows. Journal of Accounting and Economics 25(2), 133-168.

Dichev, I. D. 2013. Quality Earnings: Insights from Comparing GAAP to NIPA Earnings. Working paper.

Fama, E.F., 1981.Stock returns, real activity, inflation, and money. American Economic Review 71(4), 545-565.

Faust, J., Wright, J.H., 2007. Comparing Greenbook and reduced form forecasts using a large real time dataset. NBER working paper series, No.13397.NBER, Cambridge, MA.

Federal Reserve Bank, 2011. Survey of Professional Forecasters: Documentation. Federal Reserve Bank of Philadelphia.

Fischer, S., Merton, R.C., 1984. Macroeconomics and finance: the role of the stock market. NBER working paper series, No.1291.NBER, Cambridge, MA.

Gallo, L., Hann, R.N., Li, C., 2016. Aggregate earnings surprises, monetary policy, and stock returns. Journal of Accounting and Economics 62(1), 103-120.

Gonedes, N.J., 1973. Properties of accounting numbers: models and tests. Journal of Accounting Research 11(2), 212-237.

Greene, W.H., 2011. Econometric Analysis, 7th edition Prentice Hall, Upper Saddle River, NJ. Hann, R.N., Ogneva, M., Sapriza, H., 2012. Forecasting the macroeconomy: analysts versus economists. Working paper.

Harvey, C.R., 1989. Forecasts of economic growth from the bond and stock markets. Financial Analysts Journal 45(5), 38-45.

Henderson, J.V., Storeygard, A., Weil, D.N., 2012. Measuring economic growth from outer space. American Economic Review 102(2), 994-1028.

Konchitchki, Y., 2011. Inflation and nominal financial reporting: implications for performance and stock prices. Accounting Review 86(3), 1045-1085.

Konchitchki, Y., Patatoukas, P.N., 2014. Accounting earnings and gross domestic product. Journal of Accounting and Economics 57(1), 76-88.

Kothari, S.P., 2001. Capital markets research in accounting. Journal of Accounting and Economics 31(1-3), 105-231.

Kothari, S.P., Lewellen, J.W., Warner, J.B., 2006. Stock returns, aggregate earnings surprises, and behavioral finance. Journal of Financial Economics 79(3), 537-568.

Landefeld, J.S., Seskin, E.P., Fraumeni, B.M., 2008. Taking the pulse of the economy: measuring GDP. Journal of Economic Perspectives 22(2), 193-216.

Lev, B., Nissim, D., 2004. Taxable income, future earnings, and equity values. Accounting Review 79(4), 1039-1074.

Li, N., Richardson, S.A., Tuna, A.I., 2012.Macro to micro: country exposures, firm fundamentals and stock returns. Working paper.

McCloskey, D.N., 1993. Other things equal: Schelling's five truths of economics. Eastern Economics Journal 19(1), 109-111. 
Nallareddy, S., Sethuraman, M., Venkatachalam, M., 2018. Earnings or Cash Flows: Which is a Better Predictor of Future Cash Flows? Working paper.

Newey, W.K., West, K.D., 1987. A simple, positive semi-definite, heteroskedasticity and autocorrelation consistent covariance matrix. Econometrica 55(3), 703-708.

Patatoukas, P.N., 2014. Detecting news in aggregate accounting earnings: implications for stock market valuation. Review of Accounting Studies 19(1), 134-160.

Romer, C.D., Romer, D.H., 2000. Federal Reserve information and the behavior of interest rates. American Economic Review 90(3), 429-457.

Shevlin, T., 1990. Estimating corporate marginal tax rates with asymmetric tax treatment of gains and losses. Journal of American Taxation Association 14(1), 58-79.

Sims, C.A., 2002. The role of models and probabilities in the monetary policy process. Brookings Papers on Economic Activity, Economic Studies Program 33 (2), 1-62. (The Brookings Institution).

Stark, T., 2010. Realistic Evaluation of Real-time Forecasts in the Survey of Professional Forecasters. Federal Reserve Bank of Philadelphia (Research Department Special Report). Taylor, J.B., 1993. Discretion versus policy rules in practice. Carnegie-Rochester Conference Series on Public Policy 39(1), 195-214.

White, H., 1980. A heteroskedasticity-consistent covariance matrix estimator and a direct test for heteroskedasticity. Econometrica 48(4), 817-838.

Zarnowitz, V., Braun P., 1993. Twenty-two years of the NBER-ASA quarterly economic outlook surveys: aspects and comparisons of forecasting performance. Business Cycles, Indicators, and Forecasting, James Stock and Mark Watson, eds., Chicago: The University of Chicago 


\section{Appendix}

\section{Fig.1. Timing of SPF}

\begin{tabular}{|l|l|l|l|l|}
\hline Survey name & $\begin{array}{l}\text { Questionnaires } \\
\text { Sent to SPF } \\
\text { Panelists }\end{array}$ & $\begin{array}{l}\text { Last Quarter of } \\
\text { Accounting } \\
\text { Earnings in the } \\
\text { SPF Panelists' } \\
\text { Information Set }\end{array}$ & $\begin{array}{l}\text { Deadline for } \\
\text { Submission of } \\
\text { SPF } \\
\text { Questionnaires }\end{array}$ & $\begin{array}{l}\text { Results Released } \\
\text { to the Public }\end{array}$ \\
\hline First Quarter & $\begin{array}{l}\text { End of January } \\
\text { (after BEA's } \\
\text { advanced GDP } \\
\text { report) }\end{array}$ & Q4 & $\begin{array}{l}\text { Middle of } \\
\text { February (second } \\
\text { to third week) }\end{array}$ & $\begin{array}{l}\text { Middle to Late } \\
\text { February }\end{array}$ \\
\hline Second Quarter & $\begin{array}{l}\text { End of April (after } \\
\text { BEA's advanced } \\
\text { GDP report) }\end{array}$ & Q1 & $\begin{array}{l}\text { Middle of May } \\
\text { (second to third } \\
\text { week) }\end{array}$ & $\begin{array}{l}\text { Middle to Late } \\
\text { May }\end{array}$ \\
\hline Third Quarter & $\begin{array}{l}\text { End of July (after } \\
\text { GDP report) }\end{array}$ & Q2 & $\begin{array}{l}\text { Middle of August } \\
\text { (second to third } \\
\text { week) }\end{array}$ & $\begin{array}{l}\text { Middle to Late } \\
\text { August }\end{array}$ \\
\hline Fourth Quarter & $\begin{array}{l}\text { End of October } \\
\text { (after BEA's } \\
\text { advanced GDP } \\
\text { report) }\end{array}$ & Q3 & $\begin{array}{l}\text { Middle of } \\
\text { November } \\
\text { (second to third } \\
\text { week) }\end{array}$ & $\begin{array}{l}\text { Middle to Late } \\
\text { November }\end{array}$ \\
\hline
\end{tabular}

The figure provides details on the timeline of the SPF available from the Federal Reserve Bank of Philadelphia. Questionnaires are sent by the end of the first month after quarter $q$ ends, and the deadline for forecasters to submit their questionnaires back to the Federal Reserve Bank is the middle of the second month after quarter $q$ ends. The figure also illustrates a key aspect of my research design, namely, that the survey timing is geared towards the BEA's advance GDP report. 
Fig.2. Timing of analysis: An example, first-quarter SPF for 2010

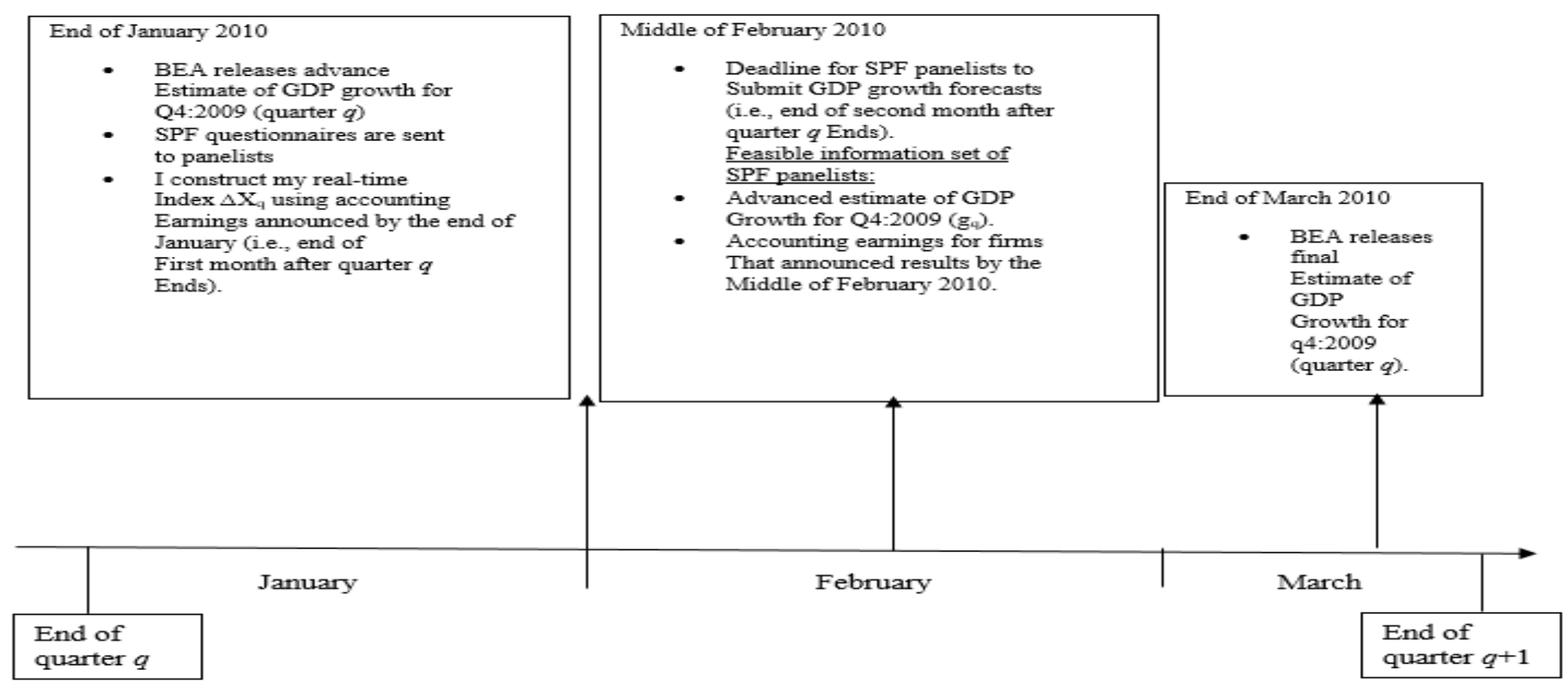

The figure provides an example that illustrates key timing aspects of my analysis. 
Table 1 - Descriptive statistics

\begin{tabular}{|c|c|c|c|c|c|c|c|c|c|c|}
\hline VARIABLES & Mean & SD & Min & P10 & P25 & P50 & P75 & P90 & Max & $\mathrm{N}$ \\
\hline Earnings & 0.0933 & 0.0377 & -0.0022 & 0.0422 & 0.0733 & 0.0961 & 0.1239 & 0.1366 & 0.1730 & 119 \\
\hline Earnings Growth & 0.0003 & 0.0208 & -0.1217 & -0.0203 & -0.0073 & 0.0015 & 0.0086 & 0.0181 & 0.0868 & 119 \\
\hline $\mathrm{CF}$ & 0.2115 & 0.2589 & -0.2549 & -0.0380 & 0.0334 & 0.1826 & 0.3179 & 0.4628 & 1.5106 & 119 \\
\hline CF Growth & 0.0286 & 0.2438 & -0.7062 & -0.2190 & -0.0970 & 0.0205 & 0.1258 & 0.2693 & 1.0408 & 119 \\
\hline Accruals & -0.1842 & 0.2587 & -1.3789 & -0.4447 & -0.2757 & -0.1534 & -0.0055 & 0.0632 & 0.2339 & 119 \\
\hline Accruals Growth & -0.0268 & 0.2445 & -0.8934 & -0.3327 & -0.1266 & -0.0232 & 0.1203 & 0.2138 & 0.6166 & 119 \\
\hline $\begin{array}{l}\text { Advance Estimate of GDP } \\
\text { Growth }\end{array}$ & 0.0445 & 0.0219 & -0.0450 & 0.0193 & 0.0344 & 0.0460 & 0.0583 & 0.0679 & 0.0970 & 119 \\
\hline $\begin{array}{l}\text { SPF Forecast of GDP } \\
\text { Growth for Quarter } q+1\end{array}$ & 0.0457 & 0.0156 & -0.0380 & 0.0327 & 0.0392 & 0.0450 & 0.0556 & 0.0607 & 0.0840 & 119 \\
\hline $\begin{array}{l}\text { SPF Forecast of GDP } \\
\text { Growth for Quarter } q+2\end{array}$ & 0.0481 & 0.0114 & -0.0084 & 0.0391 & 0.0423 & 0.0476 & 0.0567 & 0.0602 & 0.0903 & 119 \\
\hline $\begin{array}{l}\text { SPF Forecast of GDP } \\
\text { Growth for Quarter } q+3\end{array}$ & 0.0503 & 0.0089 & 0.0199 & 0.0406 & 0.0442 & 0.0497 & 0.0563 & 0.0618 & 0.0796 & 119 \\
\hline $\begin{array}{l}\text { SPF Forecast of GDP } \\
\text { Growth for Quarter } q+4\end{array}$ & 0.0510 & 0.0073 & 0.0320 & 0.0431 & 0.0455 & 0.0505 & 0.0558 & 0.0611 & 0.0690 & 119 \\
\hline $\begin{array}{l}\text { Forecast Error of GDP } \\
\text { growth for Quarter } q+1\end{array}$ & 0.0012 & 0.0253 & -0.1231 & -0.0287 & -0.0115 & 0.0035 & 0.0172 & 0.0279 & 0.0571 & 118 \\
\hline
\end{tabular}


Table 1 Cont.

\begin{tabular}{|c|c|c|c|c|c|c|c|c|c|c|}
\hline VARIABLES & Mean & SD & Min & P10 & P25 & P50 & P75 & P90 & Max & $\mathrm{N}$ \\
\hline $\begin{array}{l}\text { Forecast Error of GDP } \\
\text { growth for Quarter } q+1\end{array}$ & 0.0012 & 0.0253 & -0.1231 & -0.0287 & -0.0115 & 0.0035 & 0.0172 & 0.0279 & 0.0571 & 118 \\
\hline $\begin{array}{l}\text { Forecast Error of GDP } \\
\text { growth for Quarter } q+2\end{array}$ & -0.0020 & 0.0249 & -0.1208 & -0.0274 & -0.0152 & 0.0002 & 0.0120 & 0.0245 & 0.0625 & 117 \\
\hline $\begin{array}{l}\text { Forecast Error of GDP } \\
\text { growth for Quarter } q+3\end{array}$ & -0.0041 & 0.0262 & -0.1237 & -0.0361 & -0.0143 & -0.0030 & 0.0089 & 0.0251 & 0.0660 & 116 \\
\hline $\begin{array}{l}\text { Forecast Error of GDP } \\
\text { growth for Quarter } q+4\end{array}$ & -0.0053 & 0.0262 & -0.1249 & -0.0364 & -0.0165 & -0.0025 & 0.0088 & 0.0230 & 0.0666 & 115 \\
\hline
\end{tabular}

The table provides descriptive statistics for key variables. For firm $i$ in quarter $q$, I measure earnings $\left(X_{i, q}\right)$ as scaled quarterly net income and growth in earnings $\left(\Delta X_{i, q}\right)$ as the year-over-year change in scaled quarterly net income. I obtain real-time accounting data from the Compustat Quarterly Preliminary History. I obtain aggregate time series of earnings $\left(X_{i, q}\right)$ and earnings growth $\left(\Delta X_{i, q}\right)$ using value-weighted cross-sectional averages with weights based on market capitalization as of the beginning of each quarter. The advance estimate of GDP growth for quarter $q$ and the final estimate of GDP growth for quarter $q+k$ are obtained from the Real-Time Data Set for Macroeconomists available from the Federal Reserve Bank of Philadelphia. The mean consensus SPF forecast of GDP growth for quarter $q+k$ is available from the Federal Reserve Bank of Philadelphia. Both realized and forecasted GDP growth rates are stated in annual rates. GDP growth forecast error is the difference between realized GDP growth and the SPF consensus forecast of GDP growth. The advance estimate of GDP growth is unavailable from the Real-Time Data Set for Macroeconomists for Q4:1995 due to a government shutdown. The includes 119 quarters over the period from Q1:1988 to Q4:2017. 


\begin{tabular}{|c|c|c|c|c|}
\hline & $\begin{array}{l}\text { Earnings } \\
\text { Growth }\end{array}$ & CF Growth & Accruals Growth & $\begin{array}{l}\text { Advance } \\
\text { Estimate of } \\
\text { GDP Growth }\end{array}$ \\
\hline $\begin{array}{l}\text { Earnings } \\
\text { Growth }\end{array}$ & 1 & 0.0924 & -0.0156 & $0.4349 * * *$ \\
\hline $\begin{array}{l}\text { CF } \\
\text { Growth }\end{array}$ & $-0.1543^{*}$ & 1 & $-0.9203 * * *$ & 0.0774 \\
\hline Accruals & & & & \\
\hline Growth & $0.1544 *$ & $-0.8869 * * *$ & 1 & -0.0460 \\
\hline $\begin{array}{l}\text { Advance Estimate of GDP } \\
\text { Growth }\end{array}$ & $0.2717 * * *$ & 0.0459 & -0.0597 & 1 \\
\hline
\end{tabular}

Table 2 presents the Pearson (above diagonal) and Spearman (below diagonal) correlation coefficients for all variables. I obtain real-time accounting data from the Compustat Quarterly Preliminary History and the advance estimate of GDP growth from the Real-Time Data Set for Macroeconomists available from the Federal Reserve Bank of Philadelphia. ***, *, And * indicate statistical significance at 1, 5, and 10 percent level, respectively, using two-tailed tests. The advance estimate of GDP growth is unavailable from the Real-Time Data Set for Macroeconomists for Q4:1995 due to a government shutdown. The sample includes 119 quarters over the period from Q1:1988 to Q4:2017. 
Table 3 - Accounting earnings and future GDP growth

\begin{tabular}{|c|c|c|c|c|c|c|c|c|}
\hline VARIABLES & $\begin{array}{l}(1) \\
\text { Model A } \\
k=1\end{array}$ & $\begin{array}{l}(2) \\
\text { Model B } \\
k=1\end{array}$ & $\begin{array}{l}(3) \\
\text { Model A } \\
k=2\end{array}$ & $\begin{array}{l}(4) \\
\text { Model B } \\
k=2\end{array}$ & $\begin{array}{l}(5) \\
\text { Model A } \\
k=3\end{array}$ & $\begin{array}{l}(6) \\
\text { Model B } \\
k=3\end{array}$ & $\begin{array}{l}(7) \\
\text { Model A } \\
k=4\end{array}$ & $\begin{array}{l}(8) \\
\text { Model B } \\
k=4\end{array}$ \\
\hline Earnings growth & $\begin{array}{l}0.462 * * \\
(0.196)\end{array}$ & $\begin{array}{l}0.277^{*} \\
(0.149)\end{array}$ & $\begin{array}{l}0.450 * * * \\
(0.124)\end{array}$ & $\begin{array}{l}0.363 * * * \\
(0.117)\end{array}$ & $\begin{array}{l}0.395^{* * *} \\
(0.125)\end{array}$ & $\begin{array}{l}0.350 * * \\
(0.136)\end{array}$ & $\begin{array}{l}0.263 * \\
(0.151)\end{array}$ & $\begin{array}{l}0.203 \\
(0.161)\end{array}$ \\
\hline $\begin{array}{l}\text { Advance Estimate of } \\
\text { GDP Growth }\end{array}$ & & $\begin{array}{l}0.401 * * * \\
(0.086)\end{array}$ & & $\begin{array}{l}0.188^{*} \\
(0.095)\end{array}$ & & $\begin{array}{l}0.096 \\
(0.105)\end{array}$ & & $\begin{array}{l}0.127 \\
(0.110)\end{array}$ \\
\hline Intercept & $\begin{array}{l}0.047 * * * \\
(0.003)\end{array}$ & $\begin{array}{l}0.029 * * * \\
(0.005)\end{array}$ & $\begin{array}{l}0.046 * * * \\
(0.003)\end{array}$ & $\begin{array}{l}0.038^{* * *} \\
(0.005)\end{array}$ & $\begin{array}{l}0.046 * * * \\
(0.003)\end{array}$ & $\begin{array}{l}0.042 * * * \\
(0.005)\end{array}$ & $\begin{array}{l}0.046 * * * \\
(0.003)\end{array}$ & $\begin{array}{l}0.040 * * * \\
(0.006)\end{array}$ \\
\hline Adj. R-squared & 0.1194 & 0.1993 & 0.1186 & 0.1306 & 0.0875 & 0.0845 & 0.0346 & 0.035 \\
\hline $\mathrm{N}$ quarters & 119 & 119 & 119 & 119 & 119 & 119 & 119 & 119 \\
\hline
\end{tabular}

The table reports results from regressions of future GDP growth on current-quarter aggregate accounting earnings growth. For firm $i$ in quarter $q$, I measure earnings $\left(X_{i, q}\right)$ as scaled quarterly net income and growth in earnings $\left(\Delta X_{i, q}\right)$ as the year-over-year change in scaled quarterly net income. I obtain real-time accounting data from the Compustat Quarterly Preliminary History. I obtain aggregate time series of earnings $\left(X_{i, q}\right)$ and earnings growth $\left(\Delta X_{i, q}\right)$ using value-weighted cross-sectional averages with weights based on market capitalization as of the beginning of each quarter. The advance estimate of GDP growth for quarter $q$ and the final estimate of GDP growth for quarter $q+k$ are obtained from the Real-Time Data Set for Macroeconomists available from the Federal Reserve Bank of Philadelphia. The mean consensus SPF forecast of GDP growth for quarter $q+k$ is available from the Federal Reserve Bank of Philadelphia. Both realized and forecasted GDP growth rates are stated in annual rates. I report standard errors based on Newey and West (1987) heteroskedasticity and autocorrelation consistent standard errors with three lags. ***, *, And * indicate statistical significance at 1, 5, and 10 percent level, respectively, using two-tailed tests. The advance estimate of GDP growth is unavailable from the Real-Time Data Set for Macroeconomists for Q4:1995 due to a government shutdown. The sample includes 119 quarters over the period from Q1:1988 to Q4:2017. 
Table 4 - Accounting earnings and future GDP growth

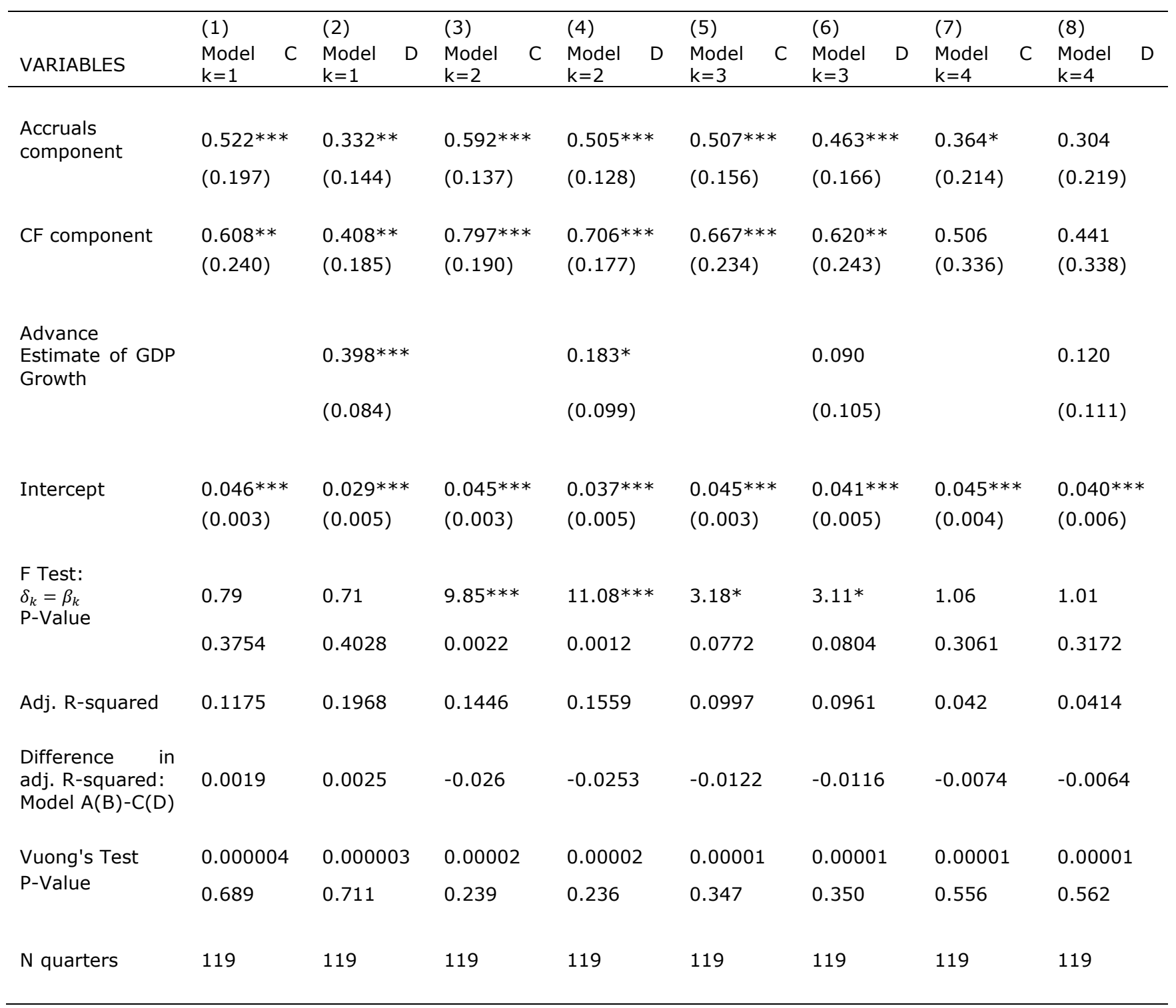

The table reports results from regressions of future GDP growth on current-quarter aggregate accounting earnings growth. CF component is aggregate accounting cash flows growth for quarter $q$, and Accrual component is aggregate accounting accruals growth for quarter $q$. I obtain real-time accounting data from the Compustat Quarterly Preliminary History. The advance estimate of GDP growth for quarter $q$ and the final estimate of GDP growth for quarter $q+k$ are obtained from the Real-Time Data Set for Macroeconomists available from the Federal Reserve Bank of Philadelphia. The mean consensus SPF forecast of GDP growth for quarter $q+k$ is available from the Federal Reserve Bank of Philadelphia. Both realized and forecasted GDP growth rates are stated in annual rates. I report standard errors based on Newey and West (1987) heteroskedasticity and autocorrelation consistent standard errors with three lags. ***,*, And * indicate statistical significance at 1, 5, and 10 percent level, respectively, using two-tailed tests. The advance estimate of GDP growth is unavailable from the Real-Time Data Set for Macroeconomists for Q4:1995 due to a government shutdown. The sample includes 119 quarters over the period from Q1:1988 to Q4:2017. 
Table 5 - Contemporaneous GDP growth and future GDP growth

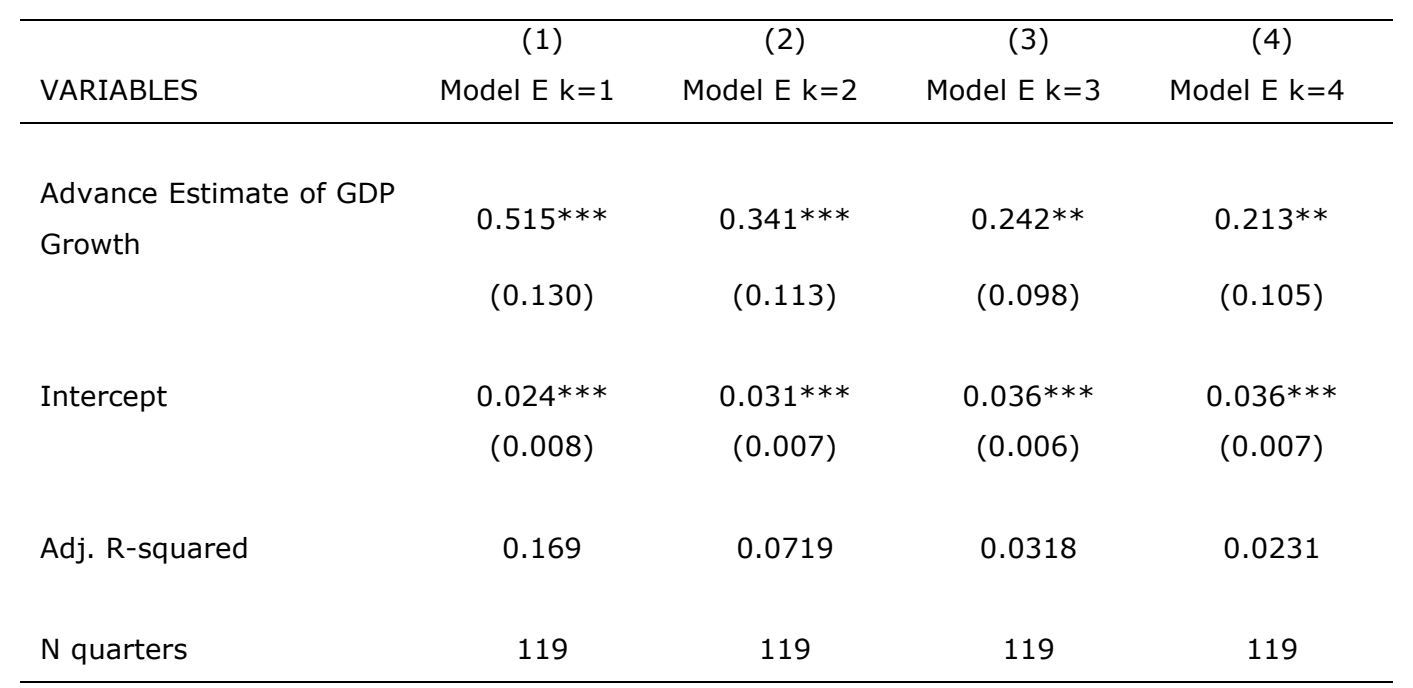

The table reports results from regressions of future GDP growth on contemporaneous GDP growth. The advance estimate of GDP growth for quarter $q$ and the final estimate of GDP growth for quarter $q+k$ are obtained from the Real-Time Data Set for Macroeconomists available from the Federal Reserve Bank of Philadelphia. The mean consensus SPF forecast of GDP growth for quarter $q+k$ is available from the Federal Reserve Bank of Philadelphia. Both realized and forecasted GDP growth rates are stated in annual rates. I report standard errors based on Newey and West (1987) heteroskedasticity and autocorrelation consistent standard errors with three lags. $* * *, *$, And * indicate statistical significance at 1, 5, and 10 percent level, respectively, using two-tailed tests. The advance estimate of GDP growth is unavailable from the Real-Time Data Set for Macroeconomists for Q4:1995 due to a government shutdown. The sample includes 119 quarters over the period from Q1:1988 to Q4:2017. 
Table 6 - Accounting earnings and future GDP growth forecast errors

\begin{tabular}{|c|c|c|c|c|c|c|c|c|}
\hline VARIABLES & $\begin{array}{l}(1) \\
\text { Model A } \\
\mathrm{k}=1\end{array}$ & $\begin{array}{l}(2) \\
\text { Model B } \\
\mathrm{k}=1\end{array}$ & $\begin{array}{l}(3) \\
\text { Model A } \\
\mathrm{k}=2\end{array}$ & $\begin{array}{l}(4) \\
\text { Model B } \\
\mathrm{k}=2\end{array}$ & $\begin{array}{l}(5) \\
\text { Model A } \\
k=3\end{array}$ & $\begin{array}{l}(6) \\
\text { Model B } \\
k=3\end{array}$ & $\begin{array}{l}(7) \\
\text { Model A } \\
\mathrm{k}=4\end{array}$ & $\begin{array}{l}(8) \\
\text { Model B } \\
\mathrm{k}=4\end{array}$ \\
\hline Earnings growth & $\begin{array}{c}0.131 \\
(0.130)\end{array}$ & $\begin{array}{c}0.176 \\
(0.143)\end{array}$ & $\begin{array}{l}0.235^{* *} \\
(0.099)\end{array}$ & $\begin{array}{c}0.290 * * * \\
(0.100)\end{array}$ & $\begin{array}{l}0.260 * * \\
(0.119)\end{array}$ & $\begin{array}{c}0.304 * * * \\
(0.114)\end{array}$ & $\begin{array}{c}0.183 \\
(0.157)\end{array}$ & $\begin{array}{l}0.177 \\
(0.150)\end{array}$ \\
\hline $\begin{array}{l}\text { Advance Estimate of } \\
\text { GDP Growth }\end{array}$ & & $\begin{array}{c}-0.098 \\
(0.069)\end{array}$ & & $\begin{array}{l}-0.120 \\
(0.111)\end{array}$ & & $\begin{array}{l}-0.096 \\
(0.121)\end{array}$ & & $\begin{array}{c}0.013 \\
(0.114)\end{array}$ \\
\hline Intercept & $\begin{array}{c}0.001 \\
(0.002)\end{array}$ & $\begin{array}{c}0.005 \\
(0.004)\end{array}$ & $\begin{array}{l}-0.002 \\
(0.003)\end{array}$ & $\begin{array}{c}0.003 \\
(0.005)\end{array}$ & $\begin{array}{l}-0.004 \\
(0.003)\end{array}$ & $\begin{array}{c}0.000 \\
(0.005)\end{array}$ & $\begin{array}{l}-0.005 \\
(0.003)\end{array}$ & $\begin{array}{l}-0.006 \\
(0.006)\end{array}$ \\
\hline Adj. R-squared & 0.0032 & 0.0006 & 0.0307 & 0.0313 & 0.0346 & 0.0314 & 0.0127 & 0.0039 \\
\hline $\mathrm{N}$ quarters & 119 & 119 & 119 & 119 & 119 & 119 & 119 & 119 \\
\hline
\end{tabular}

The table reports results from regressions of future GDP growth forecast errors on current-quarter aggregate accounting earnings growth. For firm $i$ in quarter $q$, I measure earnings $\left(X_{i, q}\right)$ as scaled quarterly net income and growth in earnings $\left(\Delta X_{i, q}\right)$ as the year-over-year change in scaled quarterly net income. I obtain real-time accounting data from the Compustat Quarterly Preliminary History. I obtain aggregate time series of earnings $\left(X_{i, q}\right)$ and earnings growth $\left(\Delta X_{i, q}\right)$ using value-weighted cross-sectional averages with weights based on market capitalization as of the beginning of each quarter. The advance estimate of GDP growth for quarter $q$ and the final estimate of GDP growth for quarter $q+k$ are obtained from the Real-Time Data Set for Macroeconomists available from the Federal Reserve Bank of Philadelphia. The mean consensus SPF forecast of GDP growth for quarter $q+k$ is available from the Federal Reserve Bank of Philadelphia. Both realized and forecasted GDP growth rates are stated in annual rates. GDP growth forecast error is the difference between realized GDP growth and the SPF consensus forecast of GDP growth. I report standard errors based on Newey and West (1987) heteroskedasticity and autocorrelation consistent standard errors with three lags. ***, *, And * indicate statistical significance at 1 , 5, and 10 percent level, respectively, using two-tailed tests. The advance estimate of GDP growth is unavailable from the Real-Time Data Set for Macroeconomists for Q4:1995 due to a government shutdown. The sample includes 119 quarters over the period from Q1:1988 to Q4:2017. 
Table 7 - Accounting earnings and future GDP growth forecast errors

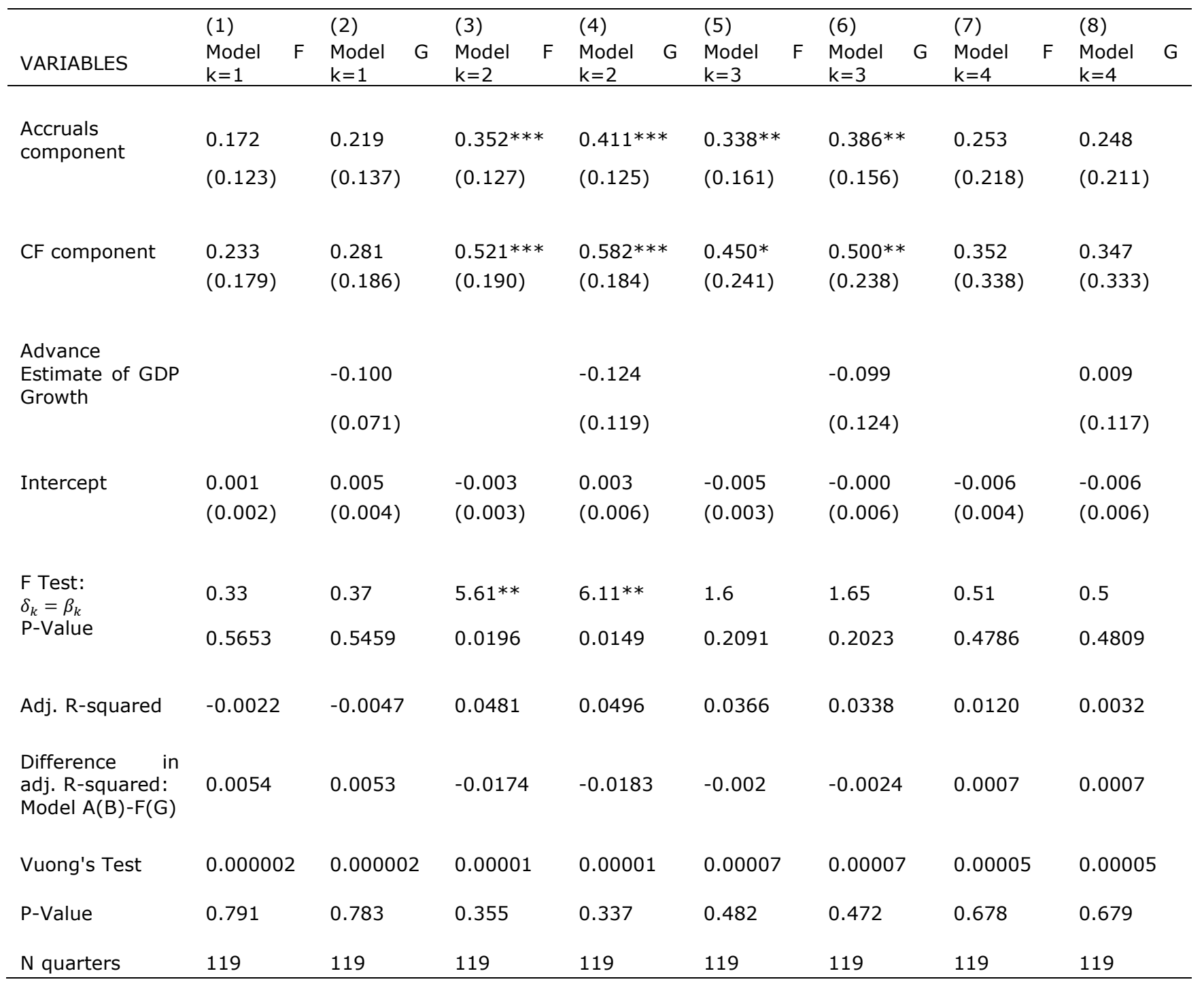

The table reports results from regressions of future GDP growth forecast errors on current-quarter aggregate accounting earnings growth. CF component is aggregate accounting cash flows growth for quarter $q$, and Accrual component is aggregate accounting accruals growth for quarter $q$. I obtain real-time accounting data from the Compustat Quarterly Preliminary History. The advance estimate of GDP growth for quarter $q$ and the final estimate of GDP growth for quarter $q+k$ are obtained from the Real-Time Data Set for Macroeconomists available from the Federal Reserve Bank of Philadelphia. The mean consensus SPF forecast of GDP growth for quarter $q+k$ is available from the Federal Reserve Bank of Philadelphia. Both realized and forecasted GDP growth rates are stated in annual rates. GDP growth forecast error is the difference between realized GDP growth and the SPF consensus forecast of GDP growth. I report standard errors based on Newey and West (1987) heteroskedasticity and autocorrelation consistent standard errors with three lags. ***, *, And * indicate statistical significance at 1 , 5 , and 10 percent level, respectively, using two-tailed tests. The advance estimate of GDP growth is unavailable from the Real-Time Data Set for Macroeconomists for Q4:1995 due to a government shutdown. The sample includes 119 quarters over the period from Q1:1988 to Q4:2017. 